\title{
Universal plant healthcare
}

\author{
Plant diseases have brought misery and suffering to human populations across the world and across millennia. \\ Declaring 2020 the International Year of Plant Health will hopefully raise awareness of this ancient yet very \\ modern threat.
}

\begin{abstract}
"It is most dreadful the state the potatoes are in Ireland; they are all tainted in the ground; it is the opinion of every one there will be no potatoes; we are greatly afraid there will be a famine this year." (Ireland, 1845)
\end{abstract}

Plant diseases kill people. The voices of observers and farmers lamenting the destruction of their crops echo across continents and down the centuries. We need farmers to feed us, but their work has always been plagued by unpredictability and dependence on parameters that they cannot control such as the weather, global market prices and, more recently, dwindling support from the general population due to poorly founded suspicions that they deliberately employ toxic chemicals to poison everybody in sight. Farmers are even more vulnerable in countries where subsistence agriculture is the primary source of income and food in rural communities.

"Some farmers cannot afford pesticides. When
they do not get them in time, they lose the
fight against fall armyworm." (Rwanda, 2019)

The Food and Agriculture Organization of the United Nations (FAO) - whose motto 'fiat panis' means 'let there be bread' in Latin uses its formidable means to monitor and help develop agriculture, with the ultimate goal of fighting hunger and increasing food security worldwide. In an attempt to focus attention on plant diseases, one of the major causes of crop failure, the FAO has named 2020 the International Year of Plant Health. Its key aims are to raise awareness about the devastating effects of plant diseases, to promote prevention and reduction of pathogen transmission, and to harmonize phytosanitary standards across countries.

\footnotetext{
"My life is being destroyed. An infected olive tree was found on another farmer's land and now they want to come and uproot mine, even if they're not sick. I grew up among these fields. These trees are my family." (Italy, 2018)
}

Domestication of plants has been a fundamental milestone in human history. The development of agriculture based on annual staple crops (mostly cereals and legumes) concentrated sources of food energy to defined sites. The increased efficiency and production of surpluses induced the previous hunter-gatherers to settle in villages and then cities. The resulting changes in social structures freed a minority of the population from

food-producing tasks and essentially started civilization as we know it.

\begin{abstract}
"Cassava is the main food crop in our area. Most residents also depend on it to generate income and now that our crop has been destroyed, we anticipate hunger. I was expecting to start harvesting in May, but my garden was destroyed by the disease. My entire plantation was destroyed. The disease has caused huge losses and that will affect our lives and our families because we depend on cassava our daily bread." (Uganda, 2016)
\end{abstract}

Since its invention, all aspects of agriculture have been continuously refined and adapted for an ever-growing human population. Better breeding technologies, larger-scale farms and standardized monoculture, optimized varieties and seeds, hybrids, mechanization, improved soil management, weather prediction and availability of fertilizers are only a few facets of modern agriculture. Producing more food, feed and fibre with less natural resources, particularly water, remains a major goal to make farming more sustainable.

\begin{abstract}
"Ng'ang's autumn wheat crop failed - his meagre 5 hectares of the high-yielding, disease resistant wheat variety was struck by a new strain of stem rust disease. It was reduced to shrivelled grain and transformed into papery chaff instead of a valuable harvest." (Kenya, 2015)
\end{abstract}

However, as German philosopher Hannah Arendt noticed, "progress and catastrophe are the opposite faces of the same coin." Agricultural improvements and higher efficiency all too often increase the probability and intensity of disasters. Droughts, fires and soil pollution due to the changing climate and unchecked human activities loom large, yet the most unpredictable of these scourges is plant disease.

"Even cows are wondering what is happening. Corn, sorghum, cowpeas, the locusts have eaten everything." (Kenya, 2020)

Plant diseases were recently estimated to cause $15-30 \%$ yield losses globally (Nat. Ecol. Evol. 3, 430-439; 2019). They can suddenly and spectacularly flare in limited geographic areas, particularly in tropical countries where the consequences for low-income farmers can be devastating. To make things worse, anthropogenic climate change will also interact with pathogen lifecycles and can boost the spread of epidemics.

\begin{abstract}
"Trees, we find, are attacked by maladies; and, indeed, what created thing is there that is exempt from these evils?" (Italy, AD 77)
\end{abstract}

Reduced product quality and yields caused by disease ultimately lead to food insecurity, starvation and death, while outbreaks and sudden proliferations of pathogens can be due to many reasons. Crop diseases have killed millions of people throughout the world, created waves of migration, modified the economy of entire countries, and inflicted colossal economic damage and suffering.

\footnotetext{
"A devastating virus swept through the groves. The trees withered. Their leaves grew to resemble craggy bird claws. The fruit was pockmarked with ring-shaped spots, hallmarks of infection. The island's papaya tradition seemed at an end." (Hawaii, 2011)
}

Modifications in ecosystems and loss of biodiversity abruptly disrupt the slow regional co-evolution between environmental reservoirs and pathogens. Interactions and old links become broken, subtle balances are perturbed. Natural barriers are not proof against the globalized trade of goods and movement of people that sometimes introduce microscopic pathogenic hitchhikers into novel environments. Genetically uniform monocultures lacking suitable resistance genes are convenient homes for emerging pests, and disaster strikes.

\section{"I realized that the damage to the crops was increasing and more devastating than ever. Since 2017, I have been harvesting low yields. I cannot get surplus to sell and pay school fees for my kids as it is my main source of income." (Kenya, 2017)}

Because the general public might not be aware of the importance of plant health and of the severe consequences of crop diseases, and because spreading information and awareness globally is an excellent strategy to improve the situation in the long term, we applaud the FAO's championing of an International Year of Plant Health, and wish it the best of success. Let's hope that one day we can live in a world in which the voices of farmers express pride for their dedication and hard work feeding the world, rather than desperation for harvests devastated by a plant disease.

Published online: 13 February 2020 https://doi.org/10.1038/s41477-020-0609-3 